\title{
HUBUNGAN USIA KEHAMILAN DENGAN KOMPLIKASI PADA BAYI BARU LAHIR DI RS AURA SYIFA KABUPATEN KEDIRI TAHUN 2017
}

\author{
Maharani Sulistiyo Putri, Ira Titisari, Arika Indah Setyarini \\ Departement Of Midwifery \\ Malang State Healty Polytechnics Indonesia
}

\begin{abstract}
The age of mother pregnancy is a time limit of mothers pregnant, which is calculated from the first day of the last menstrual period. Normal gestational age is 40 weeks or 280 days as is the custom of 9 months 10 days as in postterm pregnancy. Postterm pregnancy is a pregnancy lasting > 42 weeks. Postterm gestational age tends to have a greater risk of giving birth to infants with complications such as asphyxia, macrosomia and perinatal mortality. This may be because placental function achieves peak at 38 weeks' gestation and then decreases after 42 weeks of gestation. As a result of aging placenta, the supply of food and oxygen to the fetus decreases and the uteroplacental circulation is only about $50 \%$. The purpose of this study was to determine the relationship between gestational age with complications in newborns. The research design use analytic survey with cross sectional approach, population is taken as many as 210 respondents with sampling technique that is using purposive sampling then the big sample taken using finite formula and found the sample of 137 respondents who meet inclusion criteria. The instrument used is the medical record of patients in January - Juni 2016, measuring instrument used is documentation sheet, then data analysis in this study using crosstab conclusion from result no relation between gestational age with complication in newborn.
\end{abstract}

Keywords: Pregnancy Age, Postterm Pregnancy, Asphyxia, Macrosomia, Perinatal Death.

\section{PENDAHULUAN}

Pekajian usia kehamilan yang akurat merupakan salah satu pertimbangan paling penting yang dibuat oleh bidan selama kehamilan berlangsung. Perkiraan usia kehamilan merupakan satu-satu nya alat ukur kesehatan janin yang paling bermanfaat. Kategori pada usia kehamilan dibagi menjadi 3 yaitu : kehamilan premature $(<28$ minggu), kehamilan aterm (>37 - 41 minggu) dan kehamilan postterm ( $\geq 42$ minggu).

Setiap hari 8.000 bayi baru lahir didunia meninggal dari penyebab yang tidak dapat dicegah. Peningkatan angka morbiditas dan mortalitas pada bayi terus berkembang seiring dengan pertambahan usia kehamilan pada ibu. Mayoritasnya sekitar $75 \%$ terjadi pada minggu pertama kehidupan dan antara $25 \%$ sampai $45 \%$ terjadi dalam 24 jam pertama kehidupan seorang bayi. Penyebab utama antara lain bayi makrosomia 29\%, sepsis dan pneumonia $25 \%$ dan $23 \%$ merupakan bayi lahir dengan asfiksia dan trauma. Asfiksia neonatorum menempati penyebab ketiga dalam periode awal kehidupan (WHO, 2012).

Dari studipendahuluanyang dilakukan di RSAURA SYIFA KabupatenKediri pada tanggal 18 - 26 Desember 2016 mengenai komplikasi padabayi yang dilahirkan dari ibu kehamilan postterm dan aterm di RS AURA SYIFA KabupatenKediri,antara lain bayi yang mengalami asfiksia $455 \quad(24,40 \%)$ bayi,makrosomia dengan berat lahir $\geq 4000$ gram sebanyak $108(5,79 \%)$ bayi dan kematian perinatal 7 bayi $(0,37 \%)$ dari seluruh jumlah total 1864 bayi lahir.

\section{METODE PENELITIAN}

Penelitian ini menggunakan metode penelitian survey analitik dengan menggunakan metode pendekatan crosssectional . Teknik sampling yang 
digunakan adalah purposive sampling dengan 137responden. Alat ukur pada penelitiaan ini menggunakan lembar dokumentasi data sekunder dengan analisa data secara univariat dengan prosentase dan bivariat dengan tabulasi silang (crosstab).

\section{HASIL PENELITIAN}

1. Analisis Univariate

a. Usia Kehamilan

Tabel 4.1 Distribusi Frekuensi Kejadian Usia Kehamilan di RS AURA SYIFA Kabupaten Kediri Bulan Januari - Juni 2016.

\begin{tabular}{ccc}
\hline Usia Kehamilan & F & $\%$ \\
\hline Postterm & 45 & $32,84 \%$ \\
Aterm & 92 & $67,16 \%$ \\
\hline Total & 137 & $100 \%$
\end{tabular}

Berdasarkan Tabel 4.1 Diketahui bahwa sebagian besar usia kehamilan responden yang bersalin di RS AURA SYIFA Kabupaten Kediri (67,16\%) adalah ibu dengan usia kehamilan $\geq 37-$ 41 minggu (aterm) yaitu 92 responden. Kemudian hampir setengah dari responden yang bersalin di RS AURA SYIFA Kabupaten Kediri (32,84\%) adalah ibu dengan usia kehamilan $\geq 42$ minggu (postterm)yaitu sebesar 45 responden.

b. Asfiksia

Tabel 4.2 Distribusi Frekuensi Kejadian Asfiksia di RS AURA SYIFA Kabupaten Kediri Bulan Januari Juni 2016.

\begin{tabular}{lrc}
\hline Kejadian Asfiksia & F & $\%$ \\
\hline Ya & 78 & $56,93 \%$ \\
Tidak & 59 & $43,07 \%$ \\
\hline & Total & $100 \%$ \\
\hline
\end{tabular}

Berdasarkan Tabel 4.2 Diketahui bahwa sebagian besar responden $(56,93 \%)$ adalah bayi yang mengalami asfiksia yaitu 78 responden. Kemudian hampir setengah dari responden $(43,07 \%)$ adalah bayi yang tidak mengalami asfiksia yaitu 58 responden. c. Makrosomia

Tabel 4.3 Distribusi Frekuensi Kejadian Makrosomia di RS AURA SYIFA Kabupaten Kediri Bulan Januari Juni 2016.

\begin{tabular}{ccc}
\hline Makrosomia & $\mathrm{F}$ & $\%$ \\
\hline Ya & 61 & $44,52 \%$ \\
Tidak & 76 & $55,48 \%$ \\
\hline & Total & $100 \%$ \\
\hline
\end{tabular}

Berdasarkan Tabel 4.3 Diketahui bahwa sebagian besar responden $(55,48 \%)$ adalah bayi yang tidak mengalami makrosomia yaitu 76 responden dan hampir setengah dari responden $(44,52 \%)$ adalah bayi makrosomia yaitu 61 responden.

d. Kematian Perinatal

Tabel 4.4 Distribusi Frekuensi Kejadian Kematian Perinatal di RS AURA SYIFA Kabupaten Kediri Bulan Januari - Juni 2016.

\begin{tabular}{|c|c|c|}
\hline Kematian Perinatal & $\bar{F}$ & $\%$ \\
\hline $\mathrm{Ya}$ & 7 & $5,10 \%$ \\
\hline Tidak & 130 & $94,90 \%$ \\
\hline & Total & $100 \%$ \\
\hline
\end{tabular}
bahwa hampir seluruh responden $(94,90 \%)$ tidak mengalami kematian perinatal yaitu 130 responden. Kemudian hanya sebagian kecil responden $(5,10 \%)$ mengalami kejadian kematian perinatal yaitu 7 responden. 


\section{Analisis Bivariate}

\section{a. Hubungan Usia Kehamilan Dengan Komplikasi Asfiksia}

Tabel 4.5 Tabulasi Silang Hubungan Usia Kehamilandengan Asfiksia di RS AURA SYIFA Kabupaten Kediri Bulan Januari - Juni 2016.

asfiksia * usiakehamilan Crosstabulation

\begin{tabular}{|c|c|c|c|c|}
\hline & & \multicolumn{2}{|c|}{ usiakehamilan } & \multirow[b]{2}{*}{ Total } \\
\hline & & $\begin{array}{l}\text { postter } \\
\mathrm{m}\end{array}$ & aterm & \\
\hline \multirow[t]{10}{*}{ asfiksia ya } & Count & 24 & 55 & 79 \\
\hline & Expected Count & 25.9 & 53.1 & 79.0 \\
\hline & $\%$ within asfiksia & $30.4 \%$ & $69.6 \%$ & $100.0 \%$ \\
\hline & $\begin{array}{l}\text { \% within } \\
\text { usiakehamilan }\end{array}$ & $53.3 \%$ & $59.8 \%$ & $57.7 \%$ \\
\hline & $\%$ of Total & $17.5 \%$ & $40.1 \%$ & $57.7 \%$ \\
\hline & Count & 21 & 37 & 58 \\
\hline & Expected Count & 19.1 & 38.9 & 58.0 \\
\hline & $\%$ within asfiksia & $36.2 \%$ & $63.8 \%$ & $100.0 \%$ \\
\hline & $\begin{array}{l}\% \text { within } \\
\text { usiakehamilan }\end{array}$ & $46.7 \%$ & $40.2 \%$ & $42.3 \%$ \\
\hline & $\%$ of Total & $15.3 \%$ & $27.0 \%$ & $42.3 \%$ \\
\hline \multirow[t]{5}{*}{ Total } & Count & 45 & 92 & 137 \\
\hline & Expected Count & 45.0 & 92.0 & 137.0 \\
\hline & $\%$ within asfiksia & $32.8 \%$ & $67.2 \%$ & $100.0 \%$ \\
\hline & $\begin{array}{l}\% \text { within } \\
\text { usiakehamilan }\end{array}$ & $100.0 \%$ & $100.0 \%$ & $100.0 \%$ \\
\hline & $\%$ of Total & $32.8 \%$ & $67.2 \%$ & $100.0 \%$ \\
\hline
\end{tabular}
mengalami asfiksia terjadi pada usia kehamilan aterm $(40,1 \%)$ yaitu sebanyak 55 bayi. Dan hanya sebagian kecil bayi yang mengalami kejadian asfiksia pada usia kehamilan $(17,5 \%)$ yaitu sebanyak 24 bayi. Dari hasil perhitungan menggunakan rumus Chi- square dengan memperoleh nilai expected count yang merupakan hasil tabulasi silang menunjukkan $\chi^{2}$ hitung $(0,489) \quad<\chi^{2}$ tabel $(3,841)$ maka disimpulkan bahwa tidak ada hubungan antara usia kehamilan dengan kejadian asfiksia.

\section{b. Hubungan Usia}

\section{Kehamilandengan Komplikasi \\ Makrosomia}

Tabulasi Silang Hubungan Usia

Kehamilandengan Makrosomia

di RS AURA SYIFA Kabupaten

Kediri Bulan Januari - Juni 2016.

\begin{tabular}{|c|c|c|c|c|}
\hline \multicolumn{5}{|c|}{ makrosomia * usiakehamilan Crosstabulation } \\
\hline & & \multicolumn{2}{|c|}{ usiakehamilan } & \multirow[b]{2}{*}{ Total } \\
\hline & & $\begin{array}{l}\text { postter } \\
\mathrm{m}\end{array}$ & aterm & \\
\hline \multirow{10}{*}{$\begin{array}{l}\text { Makro Ya } \\
\text { somia }\end{array}$} & Count & 18 & 43 & 61 \\
\hline & $\begin{array}{l}\text { Expected } \\
\text { Count }\end{array}$ & 20.0 & 41.0 & 61.0 \\
\hline & $\begin{array}{l}\% \text { within } \\
\text { makrosomia }\end{array}$ & $29.5 \%$ & $70.5 \%$ & $\begin{array}{l}100.0 \\
\%\end{array}$ \\
\hline & $\begin{array}{l}\% \text { within } \\
\text { usiakehamilan }\end{array}$ & $40.0 \%$ & $46.7 \%$ & $44.5 \%$ \\
\hline & $\%$ of Total & $13.1 \%$ & $31.4 \%$ & $44.5 \%$ \\
\hline & Count & 27 & 49 & 76 \\
\hline & $\begin{array}{l}\text { Expected } \\
\text { Count }\end{array}$ & 25.0 & 51.0 & 76.0 \\
\hline & $\begin{array}{l}\text { \% within } \\
\text { makrosomia }\end{array}$ & $35.5 \%$ & $64.5 \%$ & $\begin{array}{l}100.0 \\
\%\end{array}$ \\
\hline & $\begin{array}{l}\% \text { within } \\
\text { usiakehamilan }\end{array}$ & $60.0 \%$ & $53.3 \%$ & $55.5 \%$ \\
\hline & $\%$ of Total & $19.7 \%$ & $35.8 \%$ & $55.5 \%$ \\
\hline \multirow[t]{5}{*}{ Total } & Count & 45 & 92 & 137 \\
\hline & $\begin{array}{l}\text { Expected } \\
\text { Count }\end{array}$ & 45.0 & 92.0 & 137.0 \\
\hline & $\begin{array}{l}\% \text { within } \\
\text { makrosomia }\end{array}$ & $32.8 \%$ & $67.2 \%$ & $\begin{array}{l}100.0 \\
\%\end{array}$ \\
\hline & $\begin{array}{l}\% \text { within } \\
\text { usiakehamilan }\end{array}$ & $100.0 \%$ & $100.0 \%$ & $\begin{array}{l}100.0 \\
\%\end{array}$ \\
\hline & $\%$ of Total & $32.8 \%$ & $67.2 \%$ & $\begin{array}{l}100.0 \\
\%\end{array}$ \\
\hline
\end{tabular}

Berdasarkan Tabel 4.6 Diketahui bahwa hampir setengah dari responden yang mengalami makrosomia terjadi pada usia kehamilan aterm $(31,4 \%)$ yaitu sebanyak 43 bayi. Dan hanya sebagian kecil responden yang mengalami kejadian makrosomia pada usia kehamilan postterm $(13,1 \%)$ yaitu sebanyak 18 bayi. Dari hasil perhitungan menggunakan rumusChisquare dengan memperoleh nilai expected count yang merupakan hasil tabulasi silang menunjukkan $\chi^{2}$ hitung $(0,535)<$ $\chi^{2}$ tabel $(3,841)$ maka disimpulkan bahwa 
tidak ada hubungan antara usia kehamilan dengan kejadian makrosomia.

\section{c. Hubungan Usia Kehamilan Dengan Kematian Perinatal}

Tabulasi Silang Hubungan Usia Kehamilandengan Kematian Perinatal di RS AURA SYIFA Kabupaten Kediri Bulan Januari Juni 2016.

\begin{tabular}{|c|c|c|c|c|c|}
\hline \multicolumn{5}{|c|}{ KP * usiakehamilan Crosstabulation } & \multirow[b]{3}{*}{ Total } \\
\hline & & & \multicolumn{2}{|c|}{ usiakehamilan } & \\
\hline & & & $\begin{array}{l}\text { postter } \\
\mathrm{m}\end{array}$ & aterm & \\
\hline \multirow[t]{10}{*}{$\overline{\mathrm{KP}}$} & \multirow[t]{5}{*}{ ya } & Count & 3 & 4 & 7 \\
\hline & & Expected Count & 2.3 & 4.7 & 7.0 \\
\hline & & \% within $\mathrm{KP}$ & $42.9 \%$ & $57.1 \%$ & $\begin{array}{l}100.0 \\
\%\end{array}$ \\
\hline & & $\begin{array}{l}\text { \% within } \\
\text { usiakehamilan }\end{array}$ & $6.7 \%$ & $4.3 \%$ & $5.1 \%$ \\
\hline & & $\%$ of Total & $2.2 \%$ & $2.9 \%$ & $5.1 \%$ \\
\hline & \multirow[t]{5}{*}{ tidak } & Count & 42 & 88 & 130 \\
\hline & & Expected Count & 42.7 & 87.3 & 130.0 \\
\hline & & \% within $\mathrm{KP}$ & $32.3 \%$ & $67.7 \%$ & $\begin{array}{l}100.0 \\
\%\end{array}$ \\
\hline & & $\begin{array}{l}\text { \% within } \\
\text { usiakehamilan }\end{array}$ & $93.3 \%$ & $95.7 \%$ & $94.9 \%$ \\
\hline & & $\%$ of Total & $30.7 \%$ & $64.2 \%$ & $94.9 \%$ \\
\hline \multirow[t]{5}{*}{ Total } & \multicolumn{2}{|c|}{ Count } & 45 & 92 & 137 \\
\hline & \multicolumn{2}{|c|}{ Expected Count } & 45.0 & 92.0 & 137.0 \\
\hline & \multicolumn{2}{|c|}{ \% within $\mathrm{KP}$} & $32.8 \%$ & $67.2 \%$ & $\begin{array}{l}100.0 \\
\%\end{array}$ \\
\hline & \multicolumn{2}{|c|}{ \% within usiakehamilan } & $100.0 \%$ & $100.0 \%$ & $\begin{array}{l}100.0 \\
\%\end{array}$ \\
\hline & \multicolumn{2}{|c|}{$\%$ of Total } & $32.8 \%$ & $67.2 \%$ & $\begin{array}{l}100.0 \\
\%\end{array}$ \\
\hline
\end{tabular}

Berdasarkan Tabel 4.7 Diketahui bahwa hanya sebagian kecil dari responden yang mengalami kematian perinatal baik pada usia kehamilan aterm $(2,9 \%)$ yaitu 4 bayi maupun pada usia kehamilanpostterm $(2,2 \%)$ yaitu 3 bayi. Dari hasil perhitungan menggunakan rumus Chi- square dengan memperoleh nilai expected count yang merupakan hasil tabulasi silang menunjukkan $\chi^{2}$ hitung $(0,334)<\chi^{2}$ tabel $(3,841)$ maka disimpulkan bahwa tidak ada hubungan antara usia kehamilan dengan kejadian kematian perinatal.

\section{Pembahasan}

\section{a. Hubungan Usia Kehamilan dengan Kejadian Asfiksia.}

Menurut Ranti (2015) dari penelitian yang dilakukan di RSUP Dr.M Djamil Padang memperoleh hasil demikian nilai $p$ $=0,104(\mathrm{p}>0,05)$. Hasil Penelitian ini dapat disimpulkan bahwa tidak terdapat hubungan antara usia kehamilan dengan asfiksia neonatorum di RSUP Dr. M. Djamil Padang. Diperlukan penelitian lebih lanjut mengenai hubungan usia kehamilan dengan asfiksia neonatorum.

Menurut Global Library Of Women's Medicine (GLOWM),2008. menyebutkan bahwa asfiksia terjadi karena defisit oksigen yang dibutuhkan oleh janin. Defisit tersebut diakibatkan oleh kondisi kronis seperti insifisuensi uteroplasenta dari kompresi talipusat akut yang sering terjadi bersamaan dengan kejadian oligohidramnion.

Hasil penelitian yang dilakukan di RS Aura Syifa Kabupaten Kediri pada bulan Januari - Juni tahun 2016 menunjukkan tidak ada hubungan antara usia kehamilan dan kejadian asfiksia pada bayi baru lahir. Hasil tersebut disebabkan karena kriteria inklusi yang dipilih hanya ibu usia kehamilan ini bukan termasuk oligohidramnion sehingga tidak ada hubungan antara usia kehamilan ini dengan kejadian asfiksia. Apabila ibu melakukan pemeriksaan dan kontak secara rutin dengan pelayanan kesehatan terdekat dapat mendeteksi lebih dini sehingga tidak terjadi komplikasi asfiksia pada bayi. Walaupun masih ada yang melahirkan bayi asfiksia hal ini bisa disebabkan karena faktor genetik atau faktor pendukung lainnya seperti power ibu saat mengejan kurang kuat dimana bayi berada dalam saluran reproduksi terlalu lama sehingga bayi mengalami asfiksia. 


\section{b. Hubungan Usia Kehamilan dengan Kejadian Makrosomia.}

Makrosomia adalah kondisi dimana berat bayi baru lahir melebihi standar batas berat normal bayi yaitu $\geq 4000$ gram (WHO,2013). Kelebihan berat badan pada bayi baru lahir ini dapat dipengaruhi dari faktor seperti orang tua yang bertubuh besar (obesitas), multiparitas, usia ibu yang sudah tua, janin laki - laki, ras dan suku, riwayat melahirkan bayi besar sebelumnya (WHO,2013)

Menurut Fitriana (2015), bayi dapat lahir dengan berat normal dikarenakan ibu memenuhi nutrisi seimbang selama hamil serta keteraturan ibu untuk memeriksakan kehamilan secara rutin di bidan. Oleh karena itu pemeriksaan harus rutin untuk memantau penambahan berat badan ibu hamil sehingga bayi dapat lahir dengan berat badan normal. Semakin besar berat bayi maka akan menyebabkan terjadinya komplikasi lainnya.

Menurut Medscape (2017) Faktorfaktor yang terkait dengan makrosomia janin meliputi adanya diabetes gestasional, Indeks massa tubuh sebelum kehamilan (BMI), Kenaikan berat badan selama hamil yang berlebihan, diabetes mellitus kelas A, B, dan C, faktor genetik, seks, ras, dan etnis mempengaruhi berat lahir dan risiko makrosomia, bayi laki-laki baru lahir biasanya memiliki berat lebih banyak dari pada bayi perempuan.

Menurut Prawirihardjo,2009 menyebutkan bahwa semakin bertambahnya usia kehamilan akan dapat menimbulkan adanya insifisuensi plasenta yang menyebabkan protein plasenta dan kadar DNA dibawah normal, sedangkan konsentrasi RNA meningkat. Transpor kalsium tidak terganggu, aliran natrium, kalium dan glukosa menurun. Pengangkutan dengan bahan berat molekul tinggi seperti asam amino, lemak, dan gama globulin biasanya mengalami gangguan sehingga dapat mengakibatkan gangguan pertumbuhan janin intrauterin (IUGR).
Dari teori dapat disimpulkan bahwa makin tua usia kehamilan dapat menyebabkan terjadinya insifisuensi pada plasenta, dan penyerapan sari - sari makanan pada plasenta yang akan di transportasikan ke janin tidak cukup baik. Sehingga berat badan pada bayi tidak akan bertambah secara drastis.

\section{c. Hubungan Usia Kehamilan dengan Kematian Perinatal.}

Kematian perinatal adalah kondisi dimana bayi sejak berusia 28 minggu didalam uterus hingga sampai kematian yang berumur 7 hari di luar kandungan. Jumlah atau tinggi rendahnya kematian perinatal dapat dipergunakan untuk melakukan penilaian kemampuan suatu negara untuk menyelenggarakan pelayanan kesehatan, khususnya dalam bidang obstetric (Manuaba, 2007).

Menurut Sudaryanto (2011) dalam penelitian Arinta (2012) dari sisi penyebabnya ,kematian perinatal ada dua macam yaitu endogen dan eksogen. Kematian perinatal endogen atau kematian neonatal disebabkan oleh faktor - faktor yang dibawa anak sejak lahir, yang diperoleh dari orang tuanya pada saat konsepsi. Menurut Mochtar (1998) dalam penelitian Arinta (2012) kematian perinatal disebabkan dari kondisi bayinya sendiri yaitu BBLR, asfiksia dan kelainan kongenital.

Menurut Refita (2009), hasil penelitian yang dilakukan di RSUP Dr. M.Jamil.Padang menujukkan hasil tidak ada hubungan anatara usia kehamilan dengan kejadian BBLR (berat bayi lahir rendah).

Hasil penelitian yang dilakukan di RS AURA SYIFA Kabupaten Kediri bulan Januari - Juni 2016 menunjukkan bahwa tidak ada hubungan antara usia kehamilan dengan kejadian kematian perinatal. Hal ini bisa disebabkan karena kriteria inklusi bayi yang lahir di RS AURA SYIFA bulan Januari - Juni 2016 memiliki berat $\geq 2500$ gram -4000 gram. Sehingga tidak terdapat bayi yang memiliki berat lahir 
rendah (BBLR) sedangkan kematian perinatal ini terjadi didukung dengan adanya kejadian BBLR.

\section{KESIMPULAN}

Hasil penelitian bertujuan untuk mengetahui pengaruh usia kehamilan dengan komplikasi pada bayi baru lahir di RS AURA SYIFA Kabupaten Kediri pada tahun 2016, dapat disimpulkan bahwa usia kehamilan tidak mempengaruhi komplikasi pada bayi baru lahir.

\section{DAFTAR PUSTAKA}

Arikunto,Suharsimi. 2013,Prosedur Penelitian. Jakarta :PT RINEKA CIPTA

Baur,R,Anna. 2017. Macrosomia. Amerika. Medscape. Available from http://emedicine.medscape.com/a rticle/262679-overview

Budiarto, Eko, 2012, Biostatitika, Jakarta : EGC

Berkowitz, K, and Garite, Thomas J, 2008. Postdatism. California USA,GLOWM. Available from : https://www.glowm.com/section view/heading/Postdatism/item/12 $\underline{3}$

Caughey,Aaron. 2017, Postterm Pregnancy. AJO. Available from : www.mdedge.com/amjorthopedics/ dsm/6747/obstetrics/posttermpregnancy

Cicih opitasari,2015. Maternal Education,Prematurity and the risk of birth asphyxia in selected hospital in Jakarta, Avaliable from : http://download.portalgaruda.org/art icle.php?article $=434738 \&$ val $=4884$ \&title $=$ Maternal\%20education, $\% 20$ prematurity $\% 20$ and $\% 20$ the $\% 20$ risk \%20of\%20birth\%20asphyxia\%20in $\% 20$ selected $\% 20$ hospitals $\% 20 \mathrm{in} \% 2$ 0Jakarta.

Contance, Sinclair. 2010.Buku Saku Kebidanan. Jakarta : EGC.
Cunningham, F Garry dkk. 2016.Obstetri Williams . Jakarta : EGC

Departemen Kesehatan RI. 2009. Pelayanan Obstetri Neonatal Emergensi Dasar. Jakarta

Devita Risa dan Desi Ulandari,2015.Analisis Faktor Faktor Resiko Bayi Lahir Mati Di Kota Palembang.Palembang : Sekolah Tinggi Ilmu Kesehatan 'Asyiyah Palembang. Available from:

https://www.scribd.com/doc/28964 2652/Eksis 2015-analisis-Faktorfaktor-Resiko-Bayi-Lahir-Mati-DiKota-Palembang-risa-Devita

Fajrin, Fitriana Ikhtiarinawati dan Elis Fitriani.2015.Hubungan Antara Beart Bada Bayi Baru Lahir Pada Persalinan Fisiologis Dengan Kejadian Ruptur Perineum. Vol 7 No.2. Lamongan : Universitas Islam Lamongan. Available from:http://journal.unisla.ac.id/pdf/ 19722015/2\%20jurnal\%20FITRIA NA\%209-16.pdf

Galal. M, dkk. 2012 . Postterm Preganancy. Australia. FFV IN OBGYN. Available from: https://www.ncbi.nlm.nih.gov/pmc /articles/PMC3991404/pdf/FVVin ObGyn-4-175-187.pdf.

Hardjito, Koekoeh. 2012, Pengantar Biostatistik. Magetan : penerbit Forum Ilmiah Kesehatan

Hidayat, A. Aziz Alimul. 2010. MetodePenelitianKeperawatandan TeknikAnalisaData.Jakarta :SalembaMedika.

Helmizar. 2014. Evaluasi Kebijakan Jaminan Persalinan (JAMPERSAL) Dalam Penurunan Angka Kematian Ibu dan Bayi di Indonesia.Padang.

FKM Universitas Andalas. Available from

:http://download.portalgaruda.org/ article.php?article $=149856 \& \mathrm{val}=5$ $\underline{652 \& \text { title}=\text { EVALUASI\%20KEBIJ }}$ 
AKAN\%20JAMINAN\%20PERSA LINAN\%20

Herawati, Rika. 2013, Faktor - Faktor yang Menyebabkan Terjadi Asfiksia Neonatorum Pada Bayi Baru Lahir Di Rumah Sakit Umum Daerah Kabupaten Rokan Hulu, Universitas Pasir Pengairan, Rokan Hulu. Avaliable from: http://download.portalgaruda.org/a rticle.php?article $=399449 \&$ val $=87$ 58\&title=FactorsFactors $\% 20$ Causi ng\%20Occurrence\%20of\%20asph yxia\%20neonatorum $\% 20 \mathrm{In} \% 20 \mathrm{Ne}$ wborn\%20Regional\%20General\% 20Hospital\%20RokanHlu

Levenno, J Kenneth. 2016. Obstetri Williams, Jakarta : EGC

Lowdermilk, Deitra Leonard dkk. 2013,Keperawatan Maternitas Buku 2, Jakarta : Salemba Medika.

Manuaba,Ida Ayu Chandranita, dkk,2009,Buku Ajar Patologi Obstetri,Jakarta : EGC

Meiliza Ayu Fitri, Siti Maryam, dan Rini Sulistiyowati,2012, Hubungan Kehamilan Serotinus Dengan Kejadian Asfiksia Neonatorum DI RSUD dr.ISKAK Kabupaten Tulungagung, Jurnal Ilmiah Ilmu Kebidanan Vol 4 no.1 Januari $2014 ; 6$ - 88. Available from : http://docplayer.info/32949607Jurnal-ilmiah-ilmu-kebidanan.html Muchtar, Dwie . 2012. Peran Tenaga Kesehatan Dalam Upaya Pencegahan Terjadinya Kematian Neonatal di Puskesmas Bukit Sangkal Palembang. Palembang. Available from : http://dwiistika.blogspot.co.id/201 2/10/jurnal-peran-tenagakesehatan-dalam.html

Notoatmodjo, Soekidjo.2010. Metodologi Penelitian Kesehatan. Jakarta : PTRineka Cipta .

Nurastuti, Yayang dan Deni Triasih. 2012. Hubungan Kenaikan Berat Badan Ibu Hamil dan Usia Kehamilan dengan Berat Badan Bayi Lahir . Vol 2 Rangkabitung. Available from:

file://C:/Users/User/Downloads/1 36-261-1-SM.pdf

Pongkapadang, N. Musdalipa, dkk. 2012. Faktor Risiko Kejadian Kematian Perinatal di Rumah Sakit Ibu Dan Anak Siti Fatimah Kota Makassar Tahun 2011- 2012, Makasar.Available from :http://repository.unhas.ac.id/ bitstream/handle /123456789/9546/MUSDALIPA\% 20N.PONGKAPADANG\%20K11 110619.pdf?sequence $=1$

Prawirohardjo,Sarwono,2010, Ilmu Kebidanan. Jakarta :Yayasan Bina Pustaka Sarwono Prawirohardjo.

Rahma, Andi Sitti dan Mahdian Armah, 2013. Analisis Faktor Risiko Kejadian Asfiksia Pada Bayi Baru Lahir di RSUD SYEH YUSUF GOWA dan RSUP DR WAHIDIN SUDIROHUSODO

MAKASSAR, Vol

VII.

No.1/2014,Makassar. Available from

file:///C:/Users/User/Downloads/9 46-1790-1-SM.pdf

Ranti,Jayanti. 2015.Hubungan Kehamilan Postterm Dengan Asfiksia Neonatorum di RSUP Dr.M.Djamil Padang. Padang. Available From :http://scholar.unand.ac.id/347/

Reflita dan Hasni Mastian, 2009. Faktor Faktor yang Berhubungan Dengan Berat Bayi Lahir Rendah. Padang. Available from http://ners.fkep.unand.ac.id/index. $\mathrm{php} / \mathrm{ners} / \mathrm{article} / \mathrm{view} / 98 / 92$

Rini, Setyo Dwi dan Nunik Puspitasari. 2013. Hubungan Status Kesehatan Neonatal Dengan Kematian Bayi, Surabaya, Departemen Biostatistika dan Kependudukan. Available from http://download.portalgaruda.org/a rticle.php?article $=306714 \&$ val $=10$ 
99\&title=Hubungan $\% 20$ Status $\% 2$

0Kesehatan\%20Neonatal\%20Deng an\%20Kematian\%20Bayi

Rukiyah, Ai Yeyeh dan Lia Yulianti. 2010. Asuhan Kebidanan IV (Patologi Kebidanan), Jakarta : Trans Info Media.

Saifuddin, AB.2009. Buku Acuan Nasional Maternal dan Neonatal. Jakarta : PT Bina Pustaka Sarwono Prawirohardjo.

Sondakh, Jenny. 2013. Asuhan Kebidanan dan Persalinan Bayi Baru Lahir. Jawa Timur : Erlangga.

Sukmawati, Laeli 2015 http://perpusnwu.web.id/karyailmi ah/documents/5166.pdf

Sugiyono. 2015. Metode PenelitianKuantitatifKualitatifdan $R \& D$. Bandung: Alfabeta.

Varney, Hellen dkk. 2007. Buku Ajar Asuhan Kebidanan edisi 4 Volume 1. Jakarta : EGC .

Vivian, Nanny.2014. Asuhan Neonatus Bayi dan Anak Balita. Jakarta: Salemba Medika.

Wahyuni C.S,2009.Hubungan Faktor Ibu dan Pelayanan Kesehatan dengan Kematian Perinatal di Kabupaten Pidie Tahun 2008. Available From

http://repository.usu.ac.id/xmlui/ha ndle/123456789/14689

Wandira , Arinta Kusuma dan Racmah Indawati. 2015. Faktor Penyebab Kematian Bayi di Kabupaten Sidoarjo. Sidoarjo : FKM UNAIR. Available from : http://download.portalgaruda.org/a rticle.php? article $=149856 \& \mathrm{val}=56$ 52\&title $=$ EVALUASI\%20KEBIJ AKAN\%20JAMINAN\%20PERSA LINAN\% 20

Yunita, Azmi. 2015,Hubungan Kehamilan Serotinus Dengan Kejadian Makrosomia di RSUD TUGUREJO SEMARANG, semarang, UMY. Available from :http://repository.unimus.ac.id/211/ 1/Azmi\%20Yunita..pdf 